\title{
PENDIDIKAN ISLAM HOLISTIK DAN KOMPREHENSIF
}

\author{
Zainal Azman
}

zainalazman04@gmail.com

STAI Bumi Silampari Lubuklinggau

\begin{tabular}{ll}
\hline & Abstrak \\
\hline Article History & Holistical comprehensive education can \\
Received : 10-07-2019 & be built on a religious norm, psychology, \\
Revised :11-07-2019 & culture, philosophy, management and \\
Accepted : 13-07-2019 & Tasawwuf. Islam as a universal and true \\
Keywords: & religion contains human aspect, \\
Islamic & philosophy, that has a deep, systematical, \\
education, & radical, universal, comprehensive and \\
holistic, & holistical thought, which suits on \\
comprehensive & religious values, has a strategical \\
& position, provides huge portion of \\
& teaching in building an educational and \\
& holistical comprehensive education.In \\
& Indonesia, holistical comprehensive \\
& education is not studied deeply, whereas, \\
& there are still many problems on \\
& education that need to be solved. \\
& Therefore, this study is more focused on \\
& the religion, and philosophy, related with \\
& holistical educational design that should \\
be done sustainably.
\end{tabular}

\section{Pendahuluan}

Sebagai akibat dari proses pembangunan yang lebih menekankan segi-segi materi dan hal-hal yang bersifat kebutuhan jangka pendek telah mendorong lahirnya berbagai kegiatan usaha di bidang industri dan jasa yang meningkat. Keadaan ini dari satu segi mmiliki dampak positif, karena telah ikut memecahkan problema lapangan kerja. Namun, karena jumlah lapangan kerja yang tersedia dibandingkan dengan jumlah tenaga kerja yang tersedia tidak seimbang, yakni jumlah tenaga kerja yang jauh lebih banyak daripada lapangan kerja yang tersedia, maka posisi dan daya tawar tenaga kerja menjadi sangat lemah. Mereka pada umumnya mendapatkan 
upah yang tidak layak, perlakuan yang tidak manusiawi, dan menjadikan mereka sebagai kapital dan elemen dari sebuah mesin ekonomi yang tidak memiliki jiwa dan hati nurani. Dalam keadaan demikian, maka terjadilah apa yang disebut sebagai proses dehumanisasi dan dislokasi, yang pada intinya mereduksi nilai-nilai kemanusiaan, dan menghilangkan haknya untuk menyampaikan pendapat dan kekebasannya.

Selain permasalahan di atas, munculnya gejala perasaan hidup yang kurang bermakna (loose of spiritual vision), sebagai akibat dari pandangan hidup yang terlampau menekankan aspek materi yang tidak pernah ada batas kepuasannya. Orang yang demikian itu merasa hampa, memiliki tujuan hidup yang pendek, dan tidak memiliki wawasan dan tujuan hidup jangka panjang. Mereka itu boleh jadi memiliki kedudukan, pangkat, dan harta yang berlimpah, namun mereka tidak tahu untuk apa yang mereka miliki semua itu, sehingga semunya itu tidak memiliki makna bagi kehidupan yang lebih luas, yakni suatu kehidupan yang memiliki arti dan manfaat bagi dirinya dan orang lain. Kehidupan yang bermakna itu adalah kehidupan yang dilandasi oleh pandangan spiritual, yakni kehidupan yang dinilai sebagai ibadah semata-mata ikhlas karena Allah Swt.

Pelaksanaan pendidikan yang cenderung mengutamakan aspek kognitif dan meninggalkan aspek afektif dan psikomotorik; pendidikan yang terlampau mengutamakan kecerdasan intelektual, keterampilan dan pancaindra, dan kurang memperhatikan kecerdasan emosional, spiritual, sosial, dan berbagai kecerdasan lainnya. Akibat dari keadaan yang demikian, maka lulusan pendidikan menjadi pincang, terpecah dan tidak utuh. Kecenderungan pendidikan yang demikian itu tampak terlihat pada program pendidikan dan kurikulum, proses belajar mengajar, dan lain sebagainya. Oleh karena itu, dalam merancang dan merumuskan konsep pendidikan harus dilakukan dengan berbagai pendekatan yang bersifat holistik, terutama pendekatan agama dan filsafat.

\section{Metode Penerlitian}

Penelitian ini adalah penelitian kualitatif yang bersifat studi pustaka (library research) yang menggunkan buku-buku dan literatur-literatur lainnya sebagai objek yang utama (Hadi, 2001: 3) jenis penelitian yang digunakan adalah kualitatif, yaitu penelitian yang menghasilkan 
informasi berupa catatan dan data deskriptif yang terdapat di dalam teks yang diteliti (Mantra, 2008: 30). Analisis data berupa analisis isi (content analysis). Penelitian ini menganalisis bahan pemikiran tentang pendidikan islam holistik dan komprehensif sehingga dapat diketahui makna, dan pemahaman tentang pendidikan yang komprehensf.

\section{Pembahasan}

\section{Pengertian Pendidikan Holistik Komprehensif.}

Pendidikan yang holistik komprehensif adalah pendidikan yang bertujuan memberikan kebebasan peserta didik untuk mengembangkan diri tidak saja secara intelektual, tetapi juga memfasilitasi perkembangan jiwa dan raga secara keseluruhan, sehingga tercipta manusia yang berkarakter kuat, yang mampu mengangkat harkat dan martabat bangsa, mewujudkan manusia yang merdeka sebagaimana diungkapkan Ki Hajar Dewantara "yaitu manusia yang utuh merdeka yang hidup lahir batinnya tidak tergantung kepada orang lain, akan tetapi bersandar atas kekuatan sendiri". (Nanik Rubiyanto, 2010:1). Sedangkan menurut Abuddin Nata (2013:271) pendidikan holistik komprehensif adalah "pendidikan holistik yang berbasis pada multi pendekatan, seperti pendekatan psikologi, pendekatan karakter, pendekatan sosial, emosional, spiritual, inteletual, dan seluruh spek atau komponen pendidikan; visi, misi, tujuan, kurikulum, proses belajar mengajar".

Sehubungan dengan itu, Indonesian Hiritage Foundation di Jakarta misalnya mempelopori praktik model pendidikan holistik yang berbasis karakter untuk tingkat Taman Kanak-kanak (TK) dan Sekolah Dasarr (SD). Model pendidikan ini menerapkan teori-teori sosial, emosi, kognitif, fisik, moral dan spiritual. Model ini diharapkan dapat meningkatkan kemampuan siswa berkembang sebagai individu yang terintegrasi dengan baik secara spiritual, intelektual, sosial, fisik, dan emosi yang berpikir kreatif secara mandiri, dan bertanggung jawab. (Nanik Rubiyanto, 2010:45)

Pendidikan holitik yang berbasis karakter ini bertujuan untuk membangun seluruh dimensi manusia dengan pendekatan pada pengamalan belajar yang menyenangkan dan inspiratif untuk siswa. Guru akan dilengkapi dengan pengetahuan teoritis dan praktis mengenai pendidikan yang patut dan menyenangkan, pembelajaran 
yang ramah otak, kecerdasan emosi, komunikasi efektif, penerapan pendidikan sembilan karakter secara eksplisit, yaitu mengetahui, merasakan, dan melakukan, kecerdasan majemuk, pembelajaran kooperatif, pembelajaran kontekstual, pembelajaran berbasis pertanyaan, manajemen kelas efektif, pembelajaran siswa aktif, whole language, aplikasi modul pendidikan berbasis holistik berbasis karakter, aplikasi modul karakter di ruang kelas, teknik bercerita, kreatif dan lain sebagainya. (Nanik Rubiyanto, 2010:47)

Pendidikan holistik komprehensif adalah pendidikan yang bertolak dari filsafat tentang Tuhan, Manusia, masyarakat, alam jagat raya, ilmu pengetahuan dan akhlak mulia yang didasarkan pada nilainilai agama. Hasil kajian terhadap semua aspek ini selanjutnya digunakan untuk merumuskan berbagai komponen pendidikan, yakni visi, misi, tujuan, kurikulum, tenaga pendidik dan kependidikan, peserta didik, proses belajar mengajar, sarana prasarana, pengelolaan, pembiayaan, lingkungan, kerja sama dan penilaian. Dengan demikian, pendidikan holistik komprehensif mempunyai ciri-ciri dan corak yang reflektif, integratif kurikulum, mengutamakan pembelajaran yang menyenagkan, pengembangan sumber daya manusia, dan memanfaatkan seluruh pendekatan dan metode pembelajaran yang memadukan antara yang berbasis pada guru dengan yang berbasis pada ssiwa.

\section{Akar-akar Pendidikan Holistik Komprehensif}

Pendidikan holistik komprehensif sebagaimana dikemukakan di atas, memiliki landasan normatif, filosofis, psikologis, sosiologis, epistimologis dan historis. Beberapa landasan ini dapat dijelaskan sebagai berikut:

Pertama, secara normatif pendidikan holistik komprehensif dapat dijumpai dalam berbagai ajaran agama yang berdasarkan wahyu yang diturunkan Tuhan, serta pembelajaran yang diberikan para Nabi. Di dalam kitab suci Al-Qur'an Allah Swt berfirman: "Hai orang-orang yang beriman, masuklah kamu ke dalam Islam keseluruhan, dan janganlah kamu turut langkah-langkah syaitan. Sesungguhnya syaitan itu musuh yang nyata bagimu". (QS. AlBaqarah, 2:208). "Dan Kami tidak mengutus kamu, melainkan kepada umat manusia seluruhnya sebagai pembawa berita gembira dan sebagai pemberi peringatan, tetapi kebanyakan manusia tiada mengetahui”. (QS. Sabak, 34:28). 
Di dalam ayat-ayat tersebut di atas terdapat kata kaaffah yang diartikan seluruhnya, yang mengandung arti seluruh ajaran Islam, yakni dimensi akidah, ibadah mu'amalah; atau dimensi iman, Islam dan ihsan, atau dimensi teologi, ritual dan filosofis, dan juga memeluk Islam bukan hanya ucapan, tetapi juga keyakinan dan perbuatan.

Kedua, akar landasan pendidikan holistik komprehensif secara filsuf dapat dijumpai pada penjelasan dari para filsuf sejak zaman Yunani Kuno, Filsuf Muslim sampai saat ini, yang mengemukakan tentang jiwa manusia secara utuh. Al-Farabi misalnya, mengatakan bahwa jiwa manusia memiliki tiga daya, yaitu daya al-muharrikah (makan, memelihara dan berkembang), daya al-mudrika (merasa dan imajinasi), dan daya al-nanthiqah (akal praktis dan akal teoritis). Akal teoritis ini terbagi tiga, yaitu akal potensial yang baru mempunyai potensi berpikir dalam arti melepaskan arti-arti atau bentuk dari materinya; akal aktual yang telah dapat melepaskan artiarti dari materinya, dan arti-arti itu telah memiliki wujud dalam akal dengan sebenarnya, bukan lagi dalam bentuk potensi, tetapi dalam bentuk aktual, dan akal mustafad yang telah dapat menangkan bentuk semata. (Harun Nasution, 1983:29-30).

Menurut Ibnu Sina (Harun Nasution, 1983:35-37) bahwa jiwa terbagi tiga macam, yaitu pertama, jiwa tumbuh-tumbuhan (al-nafs al-nabatiyah) yang memiliki daya makan, tumbuh dan berkembang biak; kedua, jiwa binatang (al-nafs al-hayawaniyah), yang memiliki daya gerak dan menangkap, yang terdiri dari menangkap dari luar dengan pancaindra, dan menangkap dari luar dengan indra bersama (commonsense), representasi yang menyimpan segala apa yang diterima oleh indra bersama, imajinasi yang menyusun apa yang disimpan dalam representasi, estimasi yang dapat menngkap hal-hal yang abstrak yang terlupa dari materinya, dan rekoleksi yang menyimpan hal-hal abstrak yang diterima oleh estimasi; dan ketiga, jiwa manusia (al-nafs al-nathiqah) yang memiliki dua daya, yaitu alamilah yang hubungannya dengan badan; dan al-'alimah yang hubungannya dengan hal-hal abstrak yang memiliki tingkatan akal materi (al-aql al-hayulani) yang semata-mata memiliki potensi untuk berpikir dan belum dilatih walaupun sedikit; (al-aql bi al-malakah) yang telah dilatih untuk berpikir hal-hal yang abstrak; akal aktual (alaql bi al-fi'i) yang telah dapat berpikir hal-hal abstrak; dan akal mustafad (al-aql al-mustafad), yaitu akal yang telah sanggup berpikir 
tentang hal-hal abstrak yang tidak perlu pada daya upaya; akal yang telah terlatih begitu rupa, sehingga hal-hal yang abstrak selamanya terdapat dalam akal serupa ini. Akal serupa inilah yang sanggup menerima limpahan ilmu pengetahun dari akal aktif.

Uraian di atas memperlihatkan diri manusia terdapat potensi atau daya tumbuh-tumbuhan, binatang dan manusia. Jiwa tumbuhtumbuhan berkaitan dengan potensi yang bersifat jasmani dan kecenderungannya, jiwa binatang yang berkaitan dengan fisik dan hal-hal yang bersifat hedonistik, syahwat dan ghadhab, dan jiwa manusia berkaitan dengan hal-hal yang abstrak dan nilai-nilai spiritual. Sifat seseorang yang tergantung pada jiwa manusia dari ketiga macam jiwa tersebut yang berpengaruh pada dirinya. Jika jiwa tumbuh-tumbuhan dan binatang yang berkuasa pada dirinya, maka manusia itu menyerupai binatang. Tetapi jika jiwa manusia yang mempunyai pengaruh atas dirinya, maka orang tersebut dekat menyerupai malaikat dan dekat pada kesempurnaan. Dalam hal ini daya praktis mempunyai kedudukan penting. Daya inilah yang berusaha mengontrol badan manusia, sehingga hawa nafsu yang terdapat dalam badan tidak menjadi halangan bagi daya teoretis untuk membawa manusia kepada tingkatan yang tinggi dalam usaha mencapai kesempurnaan. (Harun Nasution, 1983:37)

Landasan psikologis pendidikan holistik komprehensif juga dapat digali pada teori yang terdapat pada psikologi belajar. Dalam hubungan ini, Gagne berpendapat bahwa Learning is a change in human disposition or capability, which can be retained, andwhich is not simply ascrible to the proses of growth. Artinya belajar adalah mengubah atau membina kemampuan manusia yang dapat dilatih yang proses pertumbuhannya tidak dapat digambarkan secara sederhana (Nana Syaodah, 1997:52)

Selanjutnya dari rumpun teori belajar behaviorisme muncul teori $S-R$ Bond (hubungan stimulus dan respons), condisioning (penciptaan kondisi), dan reinforement (pemberian dorongan. Sedangkan dari rumpun teori Cognitive Gestalt Field lahir teori insight yang mengatakan bahwa belajar adalah suatu proses mengembangkan insight atau pemahaman baru atau mengubah pemahaman lama. Pemahaman terjadi apabila individu mengubah cara baru dalam mengubah unsur-unsur yang ada dalam lingkungan, termasuk struktur tubuhnya sendiri. (Nana Syaodah, 1997:54-55) 
Adanya beberapa teori belajar ini dapat digunakan landasan sebagai rumusan konsep pendidikan holistik komprehensif dari segi proses belajar mengajar. Yakni dalam proses belajar mengajar tersebut seseorang dapat mengombinasikan tentang berbagai teori tersebut sesuai dengan tujuan dan bahan pelajaran yang akan diajarkan, atau situasi pengalaman belajar yang akan dilahirkan.

Di dalam pendidikan holistik komprehensif, ranah kognitif, afektif, dan psikomotorik dengan berbagai tingkatan kemampuan itu harus dikembangkan secara seimbang dan terpadu, sehingga tidak hanya melahirkan manusia yang dapat memahami sesuatu, melainkan dapat menghayati dan mengamalkannya secara baik. Hal yang demikian penting dilakukan, karena pada setiap mata pelajaran ketiga aspek tersebut terdapat di dalamnya.

Selanjutnya, pendidikan holistik komprehensif juga didasarkan pada teori perilaku yang dikembangkan oleh Maslow, MacClelland, McGregor. Menurut Maslow, bahwa perilaku manusia dipengaruhi oleh berbagai motivasi dalam dirinya, yaitu motivasi (1) aktualisasi diri, (2) penghargaan (status, titel, simbol-simbol, promosi), (3) pengakuan sosial (menjadi pemimpin), (4) keamanan (jaminan masa pensiun, jaminan kecelakaan, dan sakit), (5) dan kebutuhan fisiologis (gaji, upah, tunjangan honorarium, perumahan, dan sebagainya). Selanjutnya dalam pandangan MacClelland, bahwa manusia memiliki kemampuan untuk berprestasi di atas kemampuan yang dimiliki orang lain yang selanjutnya disebut dengan virus $n$ ach (need for achievement). Sementara itu, dalam teori McGregor, bahwa manusia terbagi ke dalam tipe $\mathrm{X}$ dan tipe $\mathrm{Y}$. Pada tipe $\mathrm{X}$ dikatakan, bahwa sebagian besar manusia lebih suka diperintah dan tidak tertarik akan rasa tanggung jawab dan menginginkan kesamaan atas segalanya, dan karenanya manusia yang demikian itu perlu diawasi. Sementara itu, tipe Y, bahwa manusia memiliki kemampuan untuk berkreativitas motivasinya tidak hanya bersifat fisiologis (materi), melainkan lebih tinggi dari itu. Manusia yang demikian itu memiliki kemauan dan inisiatif untuk bekerja secara produktif, dan karenanya tidak perlu diawasi. (Abdul Aziz, 2008:2003-2004)

Ketiga, pendidikan holistik komprehensif dapat menggunakan landasan sosiologis, yaitu sebuah ilmu yang di dalamnya membahas tentang sekumpulan manusia yang berada di sebut teori tertentu yang memiliki tujuan dan cita-cita bersama, serta berinteraksi dan berkomunikasi antara satu dan lainnya. Selain itu, di dalam sosiologi 
juga dibahas tentang adanya stratifikasi dan struktur sosial, nilai-nilai, tradisi, budaya, agama, tingkat pendidikan, ekonomi dan kesehatan masyarakat, kepemimpinan, integrasi dan konplik, pranata sosial, ekonomi, politik, dan sebagainya, keadaan iklim cuaca, tingkat kesuburan tanah, keadaan geografis berupa daratan dan lautan, tingkat kepadatan penduduk, jalur transportasi, berbagai macam peralatan komunikasi, dan sebagainya. (Abuddin Nata, 2010:187)

Berbagai informasi yang diberikan ilmu sosiologi yang demikian itu harus dipertimbangkan dalam merancang pendidikan pendidikan holistik komprehensif, terutama dalam merumuskan visi, misi, tujuan, kurikulum, proses belajar mengajar, sarana prasarana, pembiayaan, dan lingkungan pendidikan.

Keempat, pendidikan holistik komprehensif juga dapat menggunakan kultural, yaitu landasan yang melihat bahwa kehidupan manusia ditentukan oleh sistem budaya yang dianutnya, yakni nilainilai yang dianggap luhur, teruji, dan ampuh, yang selanjutnya secara selektif diajukan sebagai acuan, referensi, atau blue print dan menghadapi dan memecahkan masalah yang dihadapi. Nilai-nilai tersebut ada di dalam mindset atau pola pikir seseorang yang tertanam kuat dan mempribadi dalam karakter hidupnya.

Dengan adanya landasan kultural tersebut, maka pendidikan holistik komprehensif akan bersikap bijaksana, adil dan arif, yakni memperlakukan dan menghargai nilai-nilai budaya terebut sebagai sebuah kekayaan yang dapat membangun kekuatan dan identitas masyarakat, serta akan menjadi stabilitas masyarakat yang dinamis. Dengan landasan kultural ini dapat dikembangkan konsep pendidikan yang multi kultural, yaitu pendidikan yang menghargai adanya perbedaan budaya masyarakat, dan menggunakannya sebagai dasar bagi pengembangan setiap anggota masyarakat.

Kelima, pendidikan holistik komprehensif dapat menggunakan landasan filsafat keilmuan, yaitu sebuah filsafat yang mengkaji tentang dimensi ontologi (sumber ilmu), epistemologi (cara dan metode dalam mengembangkan ilmu), serta aksiologi (cara memanfaatkan ilmu).

Ontologi Barat, memandang bahwa sumber ilmu terdiri dari akal, fenomena sosial, dan fenomena alam. Sedangkan dalam Islam, sumber ilmu selain akal, fenomena sosial dan fenoena alam, juga wahyu dan intuisi. Selanjutnya epistemologi Barat memandang, bahwa yang dinamakan ilmu hanyalah yang dihasilkan berdasarkan 
riset empiris eksperimen dan logika yang bebas, yang selanjutnya menghasilkan ilmu sosial, sains dan filsafat yang liberal. Dalam riset tersebut hanya menggunakan akal, dan pancaindra, sehingga yang disebut ilmu adalah yang masuk akal, yang dapat dihitung, diprediksi, dan diobervasi dengan menggunakan pacaindra dan berbagai peralatan yang bersifat fisik.

Epistimologi Barat tidak mengakui adanya hal-hal yang bersifat methaphysic, wahyu dan intuisi, dan tidak pula mengakui adanya hubungan di antara ilmu dan wahyu, ilmu dalam pandangan Barat terpisah dan tidak ada hubungannya dengan agama, dan karenanya bersifat dikhotomis. Ilmu di Barat bersifat empiris dan positivisme dan berdasar pada pandangan anthropo-centris. Hal ini berbeda dengan pandangan Islam, yang melihat bahwa antara hal-hal yang besifat physic dan metaphysic terdapat hubungan yang erat. Islam memandang bahwa yang ada (wujud) tidaklah mesti yang dapat dilihat oleh mata kepala melainkan juga oleh mata hati, atau mata batin. Islam memandang bahwa tanpa ada yang bersifat metaphysic (batin), maka yang bersifat physic (lahir) tidak dapat dijelaskan tentang asal usul dan akhir perjalannya. Islam memandang yang disebut ilmu bukan hanya ilmu sosial, sains, dan filsafat, melainkan juga ilmu agama dan ma'rifat. Berbagai ilmu tersebut saling berhubungan antara satu dan lainnya, karena semua ilmu tersebut menggunakan sumber yang diciptakan Allah Swt.

Aksiologi Barat memandang, bahwa semua itu adalah netral dan karenanya dapat digunakan sesuai dengan kehendak manusia. Ilmu dapat digunakan untuk kebaikan dan juga dapat digunakan untuk kejahatan, terserah manusia. Sedangkan dalam pandangan Islam, bahwa ilmu pengetahuan (sains) bersifat netral dari segi ontologi dan epistemologinya, sedangkan dari segi penggunaannya harus didasarkan pada petunjuk Tuhan, sehingga ilmu tersebut tidak disalah gunakan. sedangkan ilmu sosial, filsafat, ilmu agama dan ma'rifat, baik pada dataran ontologi, epistemologi tidak netral, karena ilmu-ilmu yang disebutkan terakhir ini berkaitan erat dengan perilaku manusia dan keyakinan yang antara satu dan lainnya tidaklah sama.

Keenam, pendidikan holistik komprehensif juga dapat menggunakan landasan manajemen mutu terpadu (Total Quality Management), yaitu manajemen yang melihat bahwa seluruh aspek yang terkait dengan fungsi manajemen, yakni planing, organizing, actuating, controling, superviising, evaluating, dan revising, sebagai 
satu kesatuan yang saling berkitan, antara strengtenth, weakness, opportunity dan treathment harus saling berkaitan dalam mendukung lahirnya sebuah rencana pengembangan.

Selain itu, dalam manajemen mutu ini juga harus melihat pelanggan sebagai titik sentral yang harus mendapatkan perhatian, baik pelanggan internal maupun pelanggan eksternal. Penilaian terhadap suatu yang bermutu bukan hanya dari segi hasilnya saja, melainkan juga input, proses, kemasan, pemasaran, pelayanan, penyajian, pasca penggunaan produk, dan sebagainya. Berbagai kekurangan, kritik dan saran yang diajukan pelanggan harus dilihat sebagai masukan berharga untuk perbaikan di masa mendatang. (Fandy, 2001:2-3)

Ketujuh, pendidikan holistik komprehensif juga dapat menggunakan landasan idiologis, yaitu pandangan dan cita-cita yang mendalam dan sistematik yang digunakan sebagai kerangka konseptual dalam melaksanakan suatu usaha. Pendidikan sebagai usaha besar dan strategis juga memiliki idiologi. Dalam kajian berbagai literatur terdapat idiologi-idiologi pendidikan konservatif yang terdiri dari fundamentalisme pendidikan, intelektual pendidikan, dan anarkhisme pendidikan. (William, 2008:183)

Idiologi pendidikan ini bersifat dikhotomis, karena hanya mendasarkan pada kehendak Tuhan semata-mata (theo-centris), dan mendasarkan pada manusia (anthopo-centris). Idiologi pendidikan Barat yang dikhotomis inilah yang mempengaruhi dunia pendidikan modrn saat ini, sebagaimana terlihat pada pendidikan progresivisme yang hanya mengandal pembinaan intelektual dan keterampilan manusia semata, namun moralitas dan spiritualitasnya kosong.

Dalam Islam, pendidikan diibaratkan seperti bertani yang keberhasilannya bukan hanya ditentukan oleh keadaan bibit tanaman yang unggul (nativisme), dan tanah yang subur (empirisme), melainkan juga oleh kehendak Tuhan. Allah Swt berfirman: "Maka Terangkanlah kepadaku tentang yang kamu tanam. Kamukah yang menumbuhkannya atau kamikah yang menumbuhkannya?". (QS. AlWaqi'ah, 56:63-64).

Pandangan yang demikian itu dapat dilihat pendidikan yang dilaksanakan oleh Luqman al-Hakim kepada anaknya. Allah Swt memerintahkan kepada anaknya Luqman, agar terlebih dahulu berterima kasih kepada Allah, sebelum berterima kasih kepada Luqman, karena Allah yang menjadikan dan memberikan 
kemampuan kepada Luqman untuk mendidik. Firman Allah Swt "Dan Sesungguhnya telah Kami berikan hikmat kepada Luqman, Yaitu: "Bersyukurlah kepada Allah. dan Barangsiapa yang bersyukur (kepada Allah), Maka Sesungguhnya ia bersyukur untuk dirinya sendiri; dan Barangsiapa yang tidak bersyukur, Maka sesungguhnya Allah Maha Kaya lagi Maha Terpuji". Dan (ingatlah) ketika Luqman berkata kepada anaknya, di waktu ia memberi pelajaran kepadanya: "Hai anakku, janganlah kamu mempersekutukan Allah, Sesungguhnya mempersekutukan (Allah) adalah benar-benar kezaliman yang besar". Dan Kami perintahkan kepada manusia (berbuat baik) kepada dua orang ibu- bapanya; ibunya telah mengandungnya dalam Keadaan lemah yang bertambah- tambah, dan menyapihnya dalam dua tahun. bersyukurlah kepadaku dan kepada dua orang ibu bapakmu, hanya kepada-Kulah kembalimu. (QS. Luqman, 31:12-14)

Kedelapan, pendidikan holistik komprehensif dapat pula berlandaskan pada konsep insan kamil sebagaimana yang dijumpai pada paham tasawuf sebagaimana dijumpai pada pemikiran al-Jilli. Insan kamil adalah suatu tema yang berhubungan dengan pandangan mengenai sesuatu yang dianggap mutlak. Tuhan Yang Maha Mutlak tersebut dianggap mempunyai sifat-sifat tertentu yang baik dan sempurna. Sifat sempurna inilah yang patut ditiru oleh manusia. Makin seseorang memiripkan diri kepada sifat sempurna dari yang mutlak tersebut, makin sempurnalah dirinya. Selain itu konsep insan kami juga memiliki anggapan atau keyakinan adanya yang mutlak ini mencakup nama-Nya, sifat-Nya, dan hakikat-Nya atau esensinya. (Jujun S, 1988:110)

\section{Konsep Pendidikan Holistik Komprehensif}

Kajian yang bersifat akademis pendidikan holistik komprehensif sesungguh telah lama dilakukan di Barat. Sedangkan di Indonesia kajian tersebut secara akademik belum banyak dilakukan, walaupun dalam ucapan dan kebijakan sering disinggung. Pendidikan holistik komprehensif inilah yang tampaknya menjadi salah satu alternatif yang amat diharapkan untuk memecahkan berbagai masalah pendidikan tersebut. Di antara masalah pendidikan tersebut, misalnya lulusan pendidikan yang hanya memiliki keunggulan dari segi intelektual dan keterampilan, namun kurang dari segi moral, spiritual dan akhlak, pendidikan yang cenderung menjadi komoditas yang 
diperdagangkan dan dikelola dengan pendekatan bisnis, pendidikan yang selalu tertinggal dari perkembangan zaman, pendidikan yang kurang link and mach dengan kebutuhan masyarakat, pendidikan yang cenderung membonsai atau mengkerdilkan peserta didik, pendidikan yang membosankan, pendidikan yang belum mencerahkan, lingkungan pendidikan yang kurang kondusif dan berbagai masalah lainnya.

Konsep pendidikan holistik komprehensif telah mencoba memaksimalkan aspek kreatif-inovatif pendidikan, seperti pada pembelajaran yang berbasis karakter, bercorak reflektif, mengintegrasikan kurikulum, mengutamakan pembelajaran yang menyenangkan, aktif dan mencerahkan, menyempurnakan proses transformasi pendidikan, memberdayakan interaksi keilmuan yang dinamis, memfokuskan tujuan demi pendidikan masa depan, memanfaatkan kemampuan dasariah (basic skill), mengolah pengalaman siswa, bercorak kontekstual, menumbuhkan spiritualitas anak, mewujudkan pribadi yang berintegritas, mengenalkan seni holistik untuk penggalian metodologi pembelajaran, menjawab tantangan pendidikan, menawarkan transformasi sebagai sarana problem solving pembelajaran holistik, mengkiritisi Penelitian Tindakan Kelas (PTK), pemberian hak otonomi penuh pada sekolah, Pendidikan Anak Usia Dini (PAUD) sebagai sarana pendidikan holistik, serta mencetak generasi yang berkualitas. (Nanik Rubiyanto, 2010:114)

Berdasarkan uraian di atas, tampak bahwa desain pendidikan holistik komprehensif banyak agenda yang harus diselesaikan, yakni sebanyak komponen pendidikan dengan berbagai elemen lainnya yang terkait. Berbagai aspek tersebut masih perlu kajian dan pendalaman dengan menggunakan berbagai akar landasan sebagaimana tersebut di atas. Berbagai kajian tersebut mengharuskan adanya kerja keras dari para pendidik, yakni pakar pendidikan di bidang kurikulum, proses belajar mengajar, manajemen, sarana prasarana, dan pembiayaan.

\section{Simpulan}

Pendidikan holistik komprehensif dibangun dalam rangka mengatasi berbagai masalah kemanusiaan sebagai akibat dari dampak era globalisasi, diantaranya menimbulkan kemorosan moral pada sebagian kalangan masyarakat, kurang menghargai harkat dan 
martabat manusia sebagai makhluk yang memiliki hak-hak asasi yang harus dihormati (dehumaniasi), dislokasi, munculnya gejala kepribadian yang terpecah (splite personality), merasa terasing di tengah-tengah kemodernan, munculnya hidup yang kurang bermakna, berorientasi pada hukum transaksional, pendidikan yang mengutamakan aspek kognitif, yakni wawasan dan keterampilan belaka, dan mengangggap pendidikan sebagai investasi dan komoditas yang diperdagangkan.

Pendidikan holistik komprehensif dapat dibangun dari akar landasan normatif (agama), psikologi, sosiologi, kultural, filsafat, epistemologi, budaya,manajemen dan tasawuf. Agama Islam dengan sifatnya yang univeral, mutlak, berisi ajaran tentang berbagai aspek kehidupan manusia, dan juga filsafat Islam dengan sifatnya berpikir secara mendalam, sistematik, radikal, universal, komprehensif, dan holistik yang sesuai dengan nilai-nilai ajaran agama memiliki posisi yang strategis serta menyediakan bahan-bahan yang kaya untuk membagun konsep pendidikan yang holistik komprehensif.

Pendidikan holistik komprehensif di Indonesia belum banyak dilakukan dalam bentuk kajian yang mendalam, sementara itu, berbagai masalah pendidikan yang haru dipecahkan daari waktu kewaktu demikian banyak dan beragam. Untuk itu, kajian secara lebih khusus terhadap agama dan filsafat dalam hubungannya dengan desain pendidikan holistik harus terus menerus dilakukan secara berkesinambungan. 


\section{DAFTAR PUSTAKA}

Ahmadi,. 2008. Idiologi Pendidikan Islam, Yogyakarta: Pustaka Pelajar.

Buchori, Muchtar. 2005. Pendidikan Antisipatoris, Yogyakarta: Kanisius.

Hadi, Sutrisno. 2001. Metodologi Research Jilid III, Yogyakarta: Andi Offset.

Mantra, Bagoes. Ida.2008. Filsafat Penelitian \& Metode Penelitian Sosial. Yogyakarta : Pustaka Pelajar.

Nasution, Harun. 1978. Filsafat dan Mistisme dalam Islam, Jakarta: Bulan Bintang.

Nata, Abuddin. 2010. Pendidikan Islam dengan Pendekatan Multisipliner, Jakarta: RajaGrafindo Persada.

------..2010. Ilmu Pendidikan Islam, Jakarta: Prenada Media Group.

O’Neil, William F. 2008. Idiologi-idiologi Pendidikan, (terj) Omi Insan Naomi dari judul asli Educational Ideologies: Contemporary Ekpressions of Education Philosophies, Yogyakarta: Pustaka Pelajar.

Rahman, Fazlur. 1983. Tema-tema Pokok Al-Qur'an, Bandung:Pustaka.

Rubiyanto, Nanik dan Dany Haryanto. 2010. Strategi Pembelajaran Holistik di Sekolah, Jakarta: Prestasi Pustaka Publisher.

Sukmadinata, Nana Syaodah. 1997. Pengembangan Kurikulum Teori dan Praktik, Bandung: Remaja Rosdakarya.

Suriasumantri, Jujun S. 1988. Filsafat Ilmu Sebuah Pengantar Populer, Jakarta: Sinar Harapan. 
Sihab, M. Quraish. 1996. Membumikan Al-Qur'an dan Peran Wahyu dalam Kehidupan, Bandung: Mizan.

Tjiptono, Fandy, Anastasia Diana. 2001. Total Quality Management, Yogyakarta: Andi. 